\title{
BREASTFEEDING AND ACUTE DIARRHEA AMONG CHILDREN ENROLLED IN THE FAMILY HEALTH STRATEGY
}

\author{
Floriacy Stabnow Santos, Leonardo Hunaldo dos Santos², Paula Chuproski Saldan', Felipe César Stabnow \\ Santos ${ }^{4}$, Adriana Moraes Leite ${ }^{5}$, Débora Falleiros de Mello ${ }^{6}$
}

\begin{abstract}
${ }^{1}$ Ph.D. in Sciences. Professor, Universidade Federal do Maranhão (UFMA). Imperatriz, Maranhão, Brazil. E-mail: floriacys@usp.br
${ }^{2}$ Ph.D. in Genetic Improvement. Professor at UFMA. Imperatriz, Maranhão, Brazil. E-mail: leohunaldo@gmail.com

${ }^{3}$ Ph.D. in Nursing. Professor, Universidade Estadual do Centro-Oeste. Londrina, Paraná, Brazil. E-mail: leohunaldo@gmail.com

${ }^{4}$ RN, Hospital Universitário de Brasília. Brasília, Distrito Federal, Brazil. E-mail: f7stabnow@hotmail.com

${ }^{5}$ Ph.D. in Nursing. Professor, Departamento de Enfermagem Materno Infantil e Saúde Pública da Escola de Enfermagem de Ribeirão Preto (EERP), Universidade de São Paulo (USP). Ribeirão Preto, São Paulo, Brazil. E-mail: drileite@eerp.usp.br

${ }^{6}$ Ph.D. in Nursing Professor, Departamento de Enfermagem Materno Infantil e Saúde Pública at EERP/USP. Ribeirão Preto, São Paulo, Brazil. E-mail: defmello@eerp.usp.br
\end{abstract}

\begin{abstract}
This study's objectives were to identify the prevalence of breastfeeding in children younger than 12 months of age enrolled in the Family Health Strategy and identify cases of reported acute diarrhea, associating them with breastfeeding categories and factors that interfere in the practice of breastfeeding. This descriptive and cross-sectional study, based on statistical analysis, was conducted with 854 children living in a municipality in Northeastern Brazil. The prevalence of exclusive breastfeeding among children under six months of age was $32 \%$. Exclusively breastfed children under the age of six months were less likely to experience diarrhea compared to mixed-breastfeeding children. Children using pacifiers, bottles or consuming water were less likely to be breastfed, while those consuming porridge were more likely to experience diarrhea. Strategies to promote, protect and support breastfeeding require continuous improvement, especially in regard to factors leading to early weaning, in order to achieve better indicators and improve prevention of acute diarrhea and promote child health. DESCRIPTORS: Child. Breastfeeding. Acute diarrhea.
\end{abstract}

\section{ALEITAMENTO MATERNO E DIARREIA AGUDA ENTRE CRIANÇAS CADASTRADAS NA ESTRATÉGIA SAÚDE DA FAMÍLIA}

RESUMO: Os objetivos foram identificar a prevalência do aleitamento materno em crianças menores de 12 meses cadastradas na Estratégia Saúde da Família, e identificar os casos de diarreia aguda notificados associando aos tipos de aleitamento materno e aos fatores que interferem nessa prática. Estudo descritivo, transversal, realizado nos domicílios com 854 crianças, em município do Nordeste brasileiro, com análise estatística dos dados. A prevalência do aleitamento materno exclusivo entre menores de seis meses foi de $32 \%$. Crianças menores de seis meses amamentadas exclusivamente tiveram menos chance de apresentar diarreia do que as em aleitamento misto. As que usaram chupeta, mamadeira e água tiveram menos chance de serem amamentadas. As que usaram mingau tiveram mais chance de ter diarreia. Estratégias de promoção, proteção e apoio ao aleitamento materno necessitam contínuo aprimoramento, especialmente nos fatores do desmame precoce, buscando melhores indicadores e maior impacto na prevenção contra diarreia aguda e promoção da saúde infantil. DESCRITORES: Criança. Aleitamento Materno. Diarreia aguda.

\section{AMAMANTAMIENTO MATERNO Y DIARREA AGUDA ENTRE NIÑOS REGISTRADOS EN LA ESTRATEGIA SALUD DE LA FAMILIA}

\begin{abstract}
RESUMEN: Los objetivos fueron identificar la prevalencia del amamantamiento materno en menores de 12 meses registrados en la Estrategia Salud de la Familia, identificando los casos de diarrea aguda notificados asociándolos a los tipos de amamantamiento y a factores que interfieren esta práctica. Estudio descriptivo, transversal, realizado en domicilios con 854 niños, en municipio del Nordeste brasileño, con análisis estadístico de datos. La prevalencia del amamantamiento materno exclusivo entre menores de seis meses fue 32\%. Niños menores de seis meses amamantados exclusivamente tuvieron menos probabilidades de presentar diarrea que las de amamantamiento mixto. Las que usaron chupete, biberón y agua tuvieron menos probabilidades de ser amamantadas. Las que tomaron papilla tuvieron más probabilidades de tener diarrea. Estrategias de promoción, protección y apoyo al amamantamiento materno necesitan perfeccionarse continuamente, especialmente en relación al desmame precoz, buscando mejores indicadores y mayor impacto para prevención contra diarrea aguda y promoción de la salud infantil.
\end{abstract}

DESCRIPTORES: Niño. Amamantamiento Materno. Diarrea aguda. 


\section{INTRODUCTION}

Nutrition in the early years of life greatly contributes to human development, impacting it in the short and long run. ${ }^{1}$ National and international organizations recommend breastfeeding, emphasizing the importance of exclusive breastfeeding (EB) up to the first six months of life. Complementary foods are introduced after this initial period, but breastfeeding is recommended for another two years or more..$^{2-4}$ Breastfeeding protection, promotion and support has been an important global strategy in the health field and other social sectors to improve the health condition of children.

There is evidence among children under 5 years of age that EB in the first six months of life is a crucial intervention for child survival, protecting against respiratory infections and acute diarrhea. . $^{5-7}$ Early weaning may occur more frequently in lowincome populations, especially when associated with the introduction of low nutritional value foods. As a consequence, the immunological system of these children is affected, which leads to high rates of infectious diseases. ${ }^{8}$ Promoting breastfeeding through health education activities ${ }^{9}$ has been effective in improving breastfeeding rates, thereby contributing to decreased morbidity due to infectious diseases, among which is acute diarrhea.

Acute diarrhea is one of the primary causes of morbidity and mortality among children under five years of age, with a large number of reported hospitalizations that resulted in death. ${ }^{10}$ Therefore, decreasing child diarrhea is a challenge in the health field. Even though the official data in Brazil indicate that mortality has decreased among children under the age of five, the North and Northeast concentrate the most deaths, while mortality due to diarrhea occurs among children under one year of age, which is the most vulnerable age group. ${ }^{11}$

Even though various advancements have been achieved in recent decades in the Brazilian context in regard to breastfeeding and acute diarrhea control, parameters are still below those recommended by international agencies, ${ }^{3-4}$ demonstrating the need to monitor these indicators in different contexts. Studies conducted in the Northeast show that breastfeeding duration is shorter than what is recommended, suggesting that public authorities need to mobilize and that research addressing the benefits of breastfeeding and maternal-child health should be encouraged. ${ }^{12-13}$

Taking into account the importance of monitoring breastfeeding indicators and cases of acute diarrhea, this study's objectives were to identify the prevalence of breastfeeding among children under 12 months of age enrolled in the Family Health Strategy (FHS) and to identify reported cases of acute diarrhea, associating different breastfeeding practices and factors that interfere in this practice.

\section{METHOD}

Descriptive, cross-sectional study conducted in the city of Imperatriz, MA, Brazil with children under 12 months of age, enrolled in the FSH.

Of the 1,710 children under 12 months of age covered by the 38 FHS teams in the aforementioned city, 854 children $(49.9 \%)$ participated in the study according to the following inclusion criteria: being enrolled and in follow-up in the FHS, being younger than 12 months of age at the time of data collection, either sex regardless of ethnic group, and living in the urban area of Imperatriz, as the rural area is difficult to access. Exclusion criteria were: mother or caregiver with diagnosis of mental diseases or infectious diseases such as HIV-AIDS or hepatitis, children with a chronic disease that triggers diarrhea, preterm children or twins as, generally, these children receive some nutritional complementation with formula from the time of birth, which may trigger diarrhea.

A structured instrument, adapted from the AMAMUNIC (Breastfeeding and Cities) project from the São Paulo Institute of Health, and which has been applied and analyzed in studies ${ }^{14-15}$ providing important contributions to the study of feeding practices during childhood, was used to collect data. This instrument addresses intake of breast milk, formulas and foods, including tea and other fluids in the 24 hours preceding data collection, information regarding birth and where the child has his/ her follow-up, maternal data, and also questions regarding the occurrence of acute diarrhea and hospitalizations. The instrument was applied to the mothers or other caregivers accompanying the child at the time of data collection.

Data were collected from September 2013 to July 2014 and interviews for filling out the instrument were conducted at the participants' homes by Community Health Agents (CHA) from the city, specifically trained for this purpose.

Definitions recommended by the World Health Organization ${ }^{2}$ were used to differentiate breastfeeding categories during data analysis: Exclusive Breastfeeding (the child receives only breast milk); Predominant Breastfeeding (the infant may also receive other fluids); and Complementary Feeding (the infant also receives solid or semi-solid 
food). The variables studied include: breastfeeding categories; diarrhea episodes; characteristics of child and mother; use of artificial nipples; and intake of water, tea or porridge. Information was then doubleentered and organized in a database and tabulated in Microsoft Excel 2010 spreadsheets.

The Chi-square test was used to verify whether there was association between breastfeeding categories and the number of acute diarrhea episodes. To verify strength of association between variables, Odds Ratio (OR) was used with its respective confidence interval (CI95\%). SAS was used to conduct the statistical tests. ${ }^{16}$

The study was approved by the Institutional Review Board in accordance with Resolution 466/2012, National Council of Health (396.621/2013) and in accordance with ethical standards.

\section{RESULTS}

Of the 854 children included in the study, 446 (52.2\%) were male and $408(47.8 \%)$ were female, with $152(17.8 \%)$ mothers/caregivers under 20 years of age; $627(73.4 \%)$ were aged between 20 and 34 years old; and 75 (8.8\%) caregivers were 35 years old or older. In 808 (94.6\%) cases, the mothers were the ones participating in the study and for the 46 remaining children $(5.4 \%)$, the grandmother, grandfather, aunt, nanny, father or adoptive mother participated in the study.

Of the total of children, 128 (30.4\%) were not breastfed. The remaining children were breastfeeding at the time of data collection, in the following categories: exclusive, predominant, mixed or complemented breastfeeding (Table 1). Exclusive breastfeeding was observed among children under six months of age but predominant, mixed and complementary breastfeeding were also observed. There were children who received complementary food before six months of age and others who did not breastfeed. A total of 196 (22.9\%) children experienced acute diarrhea.

Table 1 also shows that 51 (11.6\%) out of the 441 children younger than six months of age and 145 (35.1\%) out of the 413 children between six and 12 months of age, experienced acute diarrhea. The number of children with acute diarrhea was larger in the group of children between six and 12 months of age.

Table 1 - Distribution of prevalence of breastfeeding categories, Family Health Strategy. Imperatriz, MA, Brazil 2014

\begin{tabular}{lrrrr}
\hline \multirow{2}{*}{ Breastfeeding categories } & \multicolumn{2}{c}{$<$ months } & \multicolumn{2}{c}{ 6 months to } \\
& \multicolumn{1}{c}{$\mathbf{2 1 2}$ months } \\
\cline { 2 - 5 } & \multicolumn{1}{c}{$\mathbf{n}$} & \multicolumn{1}{c}{$\%$} & \multicolumn{1}{c}{$\mathbf{~}$} & \multicolumn{1}{c}{$\mathbf{0}$} \\
\hline Exclusive & 32.0 & 2 & 0.5 \\
Predominant & 89 & 20.2 & 16 & 3.9 \\
Mixed & 166 & 37.6 & 239 & 57.9 \\
Complemented & 11 & 2.5 & 62 & 15.0 \\
Were not breastfed & 34 & 7.7 & 94 & 22.7 \\
\hline Total & $\mathbf{4 4 1}$ & $\mathbf{1 0 0}$ & $\mathbf{4 1 3}$ & $\mathbf{1 0 0}$ \\
\hline
\end{tabular}

When data concerning breastfeeding and acute diarrhea are analyzed (Table 2), we verify that breastfeeding influences the likelihood of children under six months of age presenting acute diarrhea; that is, children who were breastfed were less likely to experience acute diarrhea, while those not breastfed were 2.6 times more likely to experience acute diarrhea.

Table 2 - Breastfeeding and the occurrence of acute diarrhea in children under six months of age and between six and 12 months of age, Family Health Strategy. Imperatriz, MA, Brazil 2014

\begin{tabular}{|c|c|c|c|c|c|c|}
\hline & \multicolumn{6}{|c|}{ Acute diarrhea in children $<6$ months } \\
\hline & Category & n/total & $\%$ & p-value & & $\begin{array}{c}\text { Odds ratio (CI } \\
95 \%)^{*}\end{array}$ \\
\hline \multirow{5}{*}{ Breastfeeding } & Present & $43 / 407$ & 10.5 & \multirow{2}{*}{$<0.001$} & Ref† & 1.0 \\
\hline & Absent & $08 / 34$ & 23.5 & & 2.6 & $(1.1-6.1)$ \\
\hline & \multicolumn{6}{|c|}{ Acute diarrhea in children six months to 12 months old } \\
\hline & Present & $110 / 319$ & 34.4 & \multirow{2}{*}{0.6} & Ref† & 1.0 \\
\hline & Absent & $35 / 94$ & 37.2 & & 1.1 & $(0.7-1.8)$ \\
\hline
\end{tabular}

${ }^{*} \mathrm{CI}$ 95\%: Confidence interval of 95\%; †Ref.: reference value.

Table 3 presents the relationship between breastfeeding categories and acute diarrhea. The breastfeeding category had an influence on children less than six months old. Children who received mixed breastfeeding were more likely to experience acute diarrhea when compared to other categories.

The use of pacifiers, bottles and water were factors that interfered in breastfeeding and contrib- 
uted to an increased likelihood of acute diarrhea.

Table 4 presents data regarding the use of pacifiers, bottles, water and tea. The use of pacifiers (p-valor <0.001) negatively influenced breastfeeding, increasing the likelihood of children not been breastfed by five times. The use of bottles ( $p$-value $<0.001$ ) also negatively influenced breastfeeding, that is, the less frequently bottles were used, the more frequently mothers employed breastfeeding, and vice-versa. Therefore, children who used bottles were 16 times more likely not to be breastfed. In regard to the intake of water ( $\mathrm{p}$-value<0.001), it appears that water is negatively associated with breastfeeding, so that children who ingested water were 8.5 times more likely not to be breastfed.

Table 3 - Breastfeeding category in relation to the occurrence of acute diarrhea in children under six months of age and between six and 12 months of age, Family Health Strategy. Imperatriz, MA, Brazil 2014

\begin{tabular}{|c|c|c|c|c|c|}
\hline \multirow{3}{*}{$\begin{array}{l}\text { Breastfeeding category } \\
\text { Exclusive }\end{array}$} & \multirow{3}{*}{$\frac{\text { n/total }}{02 / 141}$} & \multicolumn{4}{|c|}{ Acute diarrhea in children $<6$ months } \\
\hline & & $\%$ & p-value & \multicolumn{2}{|c|}{ Odds ratio (CI 95\%)* } \\
\hline & & 1.4 & \multirow{4}{*}{$<0.005$} & Ref† & 1.0 \\
\hline Predominant & $01 / 11$ & 9.0 & & 6.9 & $(0.5-83.4)$ \\
\hline Mixed & $12 / 89$ & 13.4 & & 10.8 & $(2.3-49.6)$ \\
\hline \multirow[t]{2}{*}{ Complemented } & $28 / 166$ & 16.8 & & 14.1 & $(3.3-60.3)$ \\
\hline & & \multicolumn{4}{|c|}{ Acute diarrhea in children between 6 and 12 months of ag } \\
\hline Exclusive & $01 / 07$ & 14.2 & & Ref† & 1.0 \\
\hline Complemented & $15 / 57$ & 26.3 & 7 & 2.1 & $(0.2-19.2)$ \\
\hline Mixed & $87 / 239$ & 36.4 & 0.1 & 3.4 & $(0.4-29.0)$ \\
\hline Predominant & 07/16 & 43.7 & & 4.6 & $(0.4-48.2)$ \\
\hline
\end{tabular}

${ }^{*} \mathrm{CI} 95 \%$ : confidence interval of $95 \%$; †Ref.: reference value.

Table 4 - Factors associated with breastfeeding in children under 12 months old, Family Health Strategy. Imperatriz, MA, Brazil 2014

\begin{tabular}{|c|c|c|c|c|c|c|}
\hline \multicolumn{7}{|c|}{ Breastfeeding } \\
\hline Variables & Category & n/total & $\%$ & p-value & Ref† & Odds ratio (CI 95\%)* \\
\hline \multirow{2}{*}{ Pacifier } & Yes & $266 / 361$ & 73.6 & \multirow{2}{*}{$<0.001$} & & 1.0 \\
\hline & No & $460 / 493$ & 93.3 & & 5.0 & $(3.2-7.6)$ \\
\hline \multirow{2}{*}{ Bottle } & Yes & $406 / 528$ & 76.8 & \multirow{2}{*}{$<0.001$} & & 1.0 \\
\hline & No & $320 / 326$ & 98.1 & & 16.0 & $(6.9-36.8)$ \\
\hline \multirow{2}{*}{ Water } & Yes & $487 / 528$ & 80.1 & \multirow{2}{*}{$<0.001$} & & 1.0 \\
\hline & No & $239 / 246$ & 97.1 & & 8.5 & $(3.9-18.4)$ \\
\hline \multirow{2}{*}{ Tea } & Yes & $122 / 147$ & 82.8 & \multirow{2}{*}{0.45} & & 1.0 \\
\hline & No & $604 / 707$ & 85.4 & & 1.2 & $(0.7-1.9)$ \\
\hline
\end{tabular}

${ }^{*} \mathrm{CI}$ 95\%: confidence interval of $95 \%$; †Ref.: reference value.

Table 5 presents data regarding the consumption of porridge and the use of pacifiers in relation to the occurrence of acute diarrhea among the children in the study.

Table 5 - The intake of porridge and use of pacifies and their relationship to acute diarrhea in children under 12 months of age, Family Health Strategy. Imperatriz, MA, Brazil 2014

\begin{tabular}{|c|c|c|c|c|c|c|}
\hline & & & & \multicolumn{3}{|c|}{ Acute diarrhea } \\
\hline & Category & n/total & $\%$ & p-value & & Odds ratio (CI 95\%)* \\
\hline \multirow{2}{*}{ Porridge } & No & $72 / 472$ & 15.2 & \multirow{2}{*}{$<0.001$} & Ref† & 1.0 \\
\hline & Yes & $124 / 382$ & 32.4 & & 2.6 & $(1.9-3.7)$ \\
\hline \multirow{2}{*}{ Pacifier } & No & $111 / 493$ & 22.5 & \multirow{2}{*}{0.72} & Ref† & 1.0 \\
\hline & Yes & $85 / 361$ & 23.5 & & 1.0 & $(0.7-1.4)$ \\
\hline
\end{tabular}

${ }^{*} \mathrm{CI} 95 \%$ : confidence interval of $95 \%$; †Ref.: reference value. 
In regard to the intake of porridge made with thickening agents ( $\mathrm{p}$-value $<0.001$ ), such as Maisena ${ }^{\circledR}$ or Cremogema ${ }^{\circledR}$ (cornstarch) or cassava paste, increased acute diarrhea is observed, showing that children who consumed porridge were 2.7 times more likely to experience acute diarrhea.

\section{DISCUSSION}

This cross-sectional study revealed a prevalence of exclusive breastfeeding at $32.0 \%$ among children under six months of age, showing that exclusive breastfeeding among children under six months of age decreased the likelihood of acute diarrhea when compared to those receiving mixed breastfeeding. Children using pacifiers, bottles, or drinking water were less likely to be breastfed and those taking porridge were more likely to have diarrhea, in the context under study. The likelihood of acute diarrhea increased among children from six to 12 months of age as the frequency of breastfeeding decreased and new foods are introduced.

Analysis of Brazilian probabilistic monitoring of information regarding breastfeeding considering comparable data among different surveys and using the same indicators among children within the same age group has shown an upward tendency of breastfeeding in Brazil. ${ }^{4-5}$ Hence, comparing data, the prevalence of breastfeeding found in Imperatriz $(32.0 \%)$ was below that found in the capital of the state, São Luís, MA, which was at $46.7 \%$, and also below the average in the country $(41.0 \%)$, according to the II Pesquisa de Prevalência de Aleitamento Materno [II Breastfeeding Prevalence Survey], which was conducted in Brazilian capitals and the Federal District. $^{5}$

Global data from different countries provided by the WHO indicate a breastfeeding rate of almost $90 \%$ immediately after birth, though it reaches $25.0 \%$ at six months of age. ${ }^{17}$ Therefore, the breastfeeding rates found in Imperatriz are below national and international rates. It is worth noting that this is the first study conducted in the city and there are no data to compare whether breastfeeding practices increased or decreased in any manner.

Considering the breastfeeding category and the occurrence of acute diarrhea, this study reveals that the children under six months of age receiving exclusive breastfeeding were less likely to experience acute diarrhea when compared to those receiving mixed breastfeeding.

It is important to pay attention to when a child reaches six months of age to initiate complementary feeding, because the early introduction of foods leads to poor absorption of nutrients and metabolic changes that can contribute to the onset of diarrheal diseases and weight loss, compromising the child's grow th. ${ }^{18}$ Hence, exclusive breastfeeding can contribute to decreased diarrhea among children under one year of age. ${ }^{18}$ A study indicates that the increased prevalence of exclusive breastfeeding between 1999 and 2008 seems to be correlated with a decreased rate of hospitalization due to diarrhea in the same period, confirming the importance of public policies that promote, protect and support breastfeeding. ${ }^{19}$ Another investigation reports that the duration of exclusive breastfeeding was higher among the children who did not experience diarrhea or respiratory morbidities. ${ }^{20}$

The use of pacifiers and bottles in this study negatively influenced breastfeeding. The results suggest that the use of these devices contributes to early weaning. A study conducted in Feira de Santana, BA, Brazil ${ }^{21}$ indicates that the use of pacifiers results in a decreased number of feedings per day, and as a consequence, less stimulation of the nippleareola complex and decreased milk production, leading to the need for supplementation. The use of artificial nipples, such as bottles, may interfere in the child's feeding practices and is associated with the incidence of acute diarrhea and mortality during childhood. ${ }^{2}$ The use of artificial nipples may represent certain difficulties experienced in breastfeeding rather than being the direct cause of breastfeeding interruption, thus, actions promoting and supporting breastfeeding should focus on the harm the use of these devices can cause to breastfeeding.

In regard to early introduction of water, we verified that breastfeeding is influenced by the intake of water. Among the reasons that lead mothers to introduce other fluids are hot weather and higher ambient temperatures, which are common in equatorial regions; as mothers become thirsty, they feel their children also need to drink water. Additionally, mothers understand the cry of their babies as being a sign that their milk is not sufficient to satiate their thirst. In general, mothers offer tea to the infant hoping to minimize discomfort caused by colic, assuming teas have therapeutic properties. ${ }^{21}$ Water and tea, however, should be avoided among children under six months of age, even in dry and hot regions, because water and tea are associated with early weaning and a consequent increase in child morbidity and mortality. ${ }^{2}$

The introduction of porridge with thickening agents was associated with an increased prevalence 
of diarrhea. The early consumption of porridge is especially higher in the Northeast of Brazil when compared to other regions, ${ }^{22}$ which is harmful to the health of children. The early consumption of foods should be taken into account when developing public policies.

In regard to the interference of environmental factors in the occurrence of morbidities, such as acute diarrhea, one study ${ }^{23}$ shows that, in addition to breastfeeding, other elements were responsible for the drop in acute diarrhea rates in Brazil, such as oral rehydration therapy, increased access to primary health care, improved basic sanitation for the population and the country's general economic development, with decreased levels of poverty.

Breastfeeding can save lives, increase the population's life expectancy and decrease public health costs, aspects that are extremely important for the Brazilian Health System. The role of programs and policies aimed to promote breastfeeding practices in Brazil has been reported and the following stands out: the expansion of the Brazilian Network of Human Milk Banks to 270 units, which shows an increased collection of milk and a larger number of donators and infants benefited; the Baby Friendly Hospital Initiative; advancements achieved regarding the NBCAL (Brazilian norm for the commercialization of baby formulas, pacifies and bottles); and social mobilization for celebrating World Breastfeeding Weeks and the National Day of Human Milk Donation on October $1^{\text {st. } .}{ }^{5}$

The breastfeeding strategies recommended by the Brazilian Ministry of Health in Imperatriz include the Baby Friendly Hospital Initiative, Human Milk Bank, Kangaroo Mother Care Unit, and Rooming-in Care of Newborn Infants. Professional training on how to handle breastfeeding is also provided and the National Week of Breastfeeding Encouragement is celebrated. These initiatives are consonant with Brazilian strategies in which various actions are recommended to promote, encourage and support breastfeeding, such as the Baby Friendly Hospital Initiative, Human Milk Bank, Rede Amamenta Brasil [Breastfeed Brazil Network] and educational actions in prenatal care, as well as the International Baby Food Action Network (IBFAN), and the continuing use of mass communication means and initiatives from organizations in civil society. ${ }^{24}$

Another aspect to consider involves the Family Health Strategy (formerly named the Family Health Program) implemented in Brazil beginning in 1996. It represents the possibility to respond to health conditions using knowledge acquired by its staff while providing care to the population, regarding social and human dimensions. ${ }^{25}$ The Family Health Strategy's teams, however, face many challenges and need to acquire technologies aimed to strengthen the population's potential for health-changing health practices and the production of care, which are necessary to reconstruct more supportive, welcoming health practices and, consequently, produce greater problem-solving capacity. ${ }^{26}$ Therefore, educational practices and actions to promote, encourage and support breastfeeding, as well as to control acute diarrhea need to be expanded. Breastfeeding is presenting an upward trend in Brazil; ${ }^{4}$ however important challenges need to be overcome and to speed up the growth of this practice in order to fully comply with the relevant recommendations and take advantage of its benefits.

\section{CONCLUSION}

This study reveals that the averages of exclusive breastfeeding among children under six months of age and among those from six to 12 months of age were much lower than those recommended by the Ministry of Health.

Children from six to 12 months of age experienced more episodes of diarrhea and hospitalization than children under six months of age.

Breastfed children presented lower prevalence of acute diarrhea and those who used pacifiers, bottles or consumed water were less likely to be breastfed, while the use of porridge favored the occurrence of acute diarrhea.

It is worth noting that strategies to promote, protect and support breastfeeding within the Family Health Strategy need to be continually improved to seek better breastfeeding indicators, especially exclusive breastfeeding, and to more effectively prevent acute diarrhea and promote child health.

Acute diarrhea is a condition that expresses an inequality in the health field, particularly among children under one year of age experiencing living conditions that expose them to the risk of death. In this sense, public policies regarding social, economic, environmental, cultural, and health that are based on the principle of equity are crucial to meeting the different local needs of each region. The results presented are important to guiding local actions and helping health professionals to focus attention on the factors associated with early weaning, as well as providing focus on the importance and benefits arising from prolonged breastfeeding and control of child morbidity. 
The main limitation of this study is the data collection process that focused on children enrolled in the Family Health Strategy living in the urban area. Hence, research that allows the analysis of factors in other contexts and also that verifies the quantity and quality of foods consumed by children will be enriching and contribute to assessing nutritional aspects and how these aspects interface with the prevention of morbidities during childhood.

\section{REFERENCES}

1. Bhutta ZA, Das JK, Rizvi A, Gaffey MF, Walker $\mathrm{N}$, Horton $\mathrm{S}$, et al. Evidence-based interventions for improvement of maternal and child nutrition: what can be done and at what cost? Lancet. 2013; 382(9890):452-77.

2. Ministério da Saúde (BR). Secretaria de Atenção à Saúde. Departamento de Atenção Básica. Dez passos para uma alimentação saudável: guia alimentar para crianças menores de dois anos: um guia para o profissional de saúde da atenção básica. Brasília (DF): Ministério da Saúde; 2013.

3. World Health Organization (WHO). Indicators for assessing infant and young child feeding practices part 2: measurement. Geneva: WHO; 2010.

4. Venancio SI, Saldiva SRDM, Monteiro CA. Secular trends in breastfeeding in Brazil. Rev Saúde Pública. 2013(6);47:1205-8.

5. Venancio SI, Escuder MML, Saldiva SRDM, Giugliani ERJ. Breastfeeding practice in the Brazilian capital cities and the Federal District: current status and advances. J Pediatr. 2010; 86(4):317-24.

6. Lamberti LM, Fischer Walker CL, Noiman A, Victora C, Black RE. Breastfeeding and the risk for diarrhea morbidity and mortality. BMC Public Health. 2011; 11(Suppl 3):S15.

7. Suwantika AA, Postma MJ. Effect of breastfeeding promotion interventions on cost-effectiveness of rotavirus immunization in Indonesia. BMC Public Health. 2013; 13:1106.

8. Dias MCAP, Freire LMS, Franceschini SCC. Recomendações para alimentação complementar de crianças menores de dois anos. Rev Nutr Campinas. 2010; 23(3):475-86.

9. D'Artibale, EF; Bercini, LO. Early contact and breastfeeding: meanings and experiences. Texto Contexto Enferm. 2014; 23(1):109-17.

10. Liu L, Oza S, Hogan D, Perin J, Rudan I, Lawn JE, et al. Global, regional, and national causes of child mortality in 2000-13, with projections to inform post-2015 priorities: an updated systematic analysis. Lancet. 2015; 385(9966):430-40.

11. Bühler HF, Ignotti E, Neves SMAS, Hacon SS. Análise espacial de indicadores integrados determinantes da mortalidade por diarreia aguda em crianças menores de 1 ano em regiões geográficas. Ciênc Saúde Coletiva. 2014; 19(10):4131-40.

12. Oliveira MGOA, Lira PIC, Batista Filho M, Lima MC. Factors associated with breastfeeding in two municipalities with low human development index in Northeast Brazil. Rev Bras Epidemiol. 2013; 16(1):178-89.

13. Cavalcanti SH, Caminha MFC, Figueiroa JN, Serva VMSBD, Cruz RSBLC, Lira PIC, et al. Factors associated with breastfeeding practice for at least six months in the state of Pernambuco, Brazil. Rev Bras Epidemiol. 2015; 18(1):208-19.

14. Sadeck LSR, Leone CR. Infant breastfeeding prevalence in the city of São Paulo, Brazil, 2008. Cad Saúde Pública. 2013; 29(2):397-402.

15. Passanha A, Benício MHDA, Venâncio SI, Reis MCG. Implementation of the Brazilian Breastfeeding Network and prevalence of exclusive breastfeeding. Rev Saúde Pública. 2013;47(6):1141-8.

16. Statistical Analysis System (SAS). SAS software: user's guide. Version 8.2. Cary; 2000.

17. World Health Organization (WHO). Infant and young child feeding data by country. 2009. [acesso 29 dez. 2009]. Disponível em: http:/ / www.who.int/ nutrition/databases/infantfeeding/countries/en/ index.html>.

18. Boccolini CS, Boccollini PMM. Breastfeeding and protection against diarrhea: an integrative review of literature, 2008. Epidemiol Serv Saúde. 2011; 20(1):1926.

19. Boccolini CS, Boccollini PMM, Carvalho ML, Oliveira MIC. Padrões de aleitamento materno exclusivo e internação por diarreia entre 1999 e 2008 em capitais brasileiras. Ciênc Saúde Coletiva. 2012; 17(7):1857-63.

20. Bernardi JR, Gama CM, Vitolo MR. Impacto de um programa de atualização em alimentação infantil em unidades de saúde na prática do aleitamento materno e na ocorrência de morbidade. Cad Saúde Pública. 2011; 27(6):1213-22.

21. Vieira GO, Martins CC, Vieira TO, Oliveira NF, Silva LR. Factors predicting early discontinuation of exclusive breastfeeding in the first month of life. J Pediatr. 2010; 86(5):441-4.

22. Saldiva SRDM, Venancio SI, Gouveia AGC, Castro ALS, Escuder MML, Giugliani ERJ. Influência regional no consumo precoce de alimentos diferentes do leite materno em menores de seis meses residentes nas capitais brasileiras e Distrito Federal. Cad Saúde Pública. 2011; 27(11):2253-62.

23. Sastry N, Burgard S. Changes in diarrheal disease and treatment among Brazilian children from 1986 to 1996. Popul Res Policy Rev. 2011; 30:81-100.

24. Caminha MFC, Batista Filho M, Serva VB, Arruda IKG, Figueiroa JN, Lira PIC. Time trends and factors associated with breastfeeding in the state of Pernambuco, Northeastern Brazil. Rev Saúde Pública. 2010; 44(2):240-8. 
25. Leão CDA, Calderia AP, Oliveria MMC. Atributos da atenção primária na assistência à saúde da criança: avaliação dos cuidadores. Rev Bras Saúde Materno Infantil. 2011; 11(3):323-34.
26. Costa GD, Cotta RMM, Ferreira MLSM, Reis JR, Franceschini SCC. Saúde da família: desafios no processo de reorientação do modelo assistencial. Rev Bras Enferm. 2009; 62(1):113-8. 